\title{
Simulating Soil Moisture under Different Tillage Practices, Cropping Systems and Organic Fertilizers Using CropSyst Model, in Matuu Division, Kenya
}

\author{
Muli M. N. ${ }^{1}$, Onwonga R. N. ${ }^{1}$, Karuku G. N. ${ }^{1}$, Kathumo V. M. ${ }^{1} \&$ Nandukule M. O. ${ }^{1}$ \\ ${ }^{1}$ Department of Land Resource Management and Agricultural Technology, University of Nairobi, Nairobi, \\ Kenya \\ Correspondence: Onwonga R. N., Department of Land Resource Management and Agricultural Technology, \\ University of Nairobi, P.O. Box 29053-00625 Nairobi, Kenya. E-mail: dr.onwonga@gmail.com
}

Received: October 9, 2014 Accepted: November 21, 2014 Online Published: January 15, 2015

doi:10.5539/jas.v7n2p26 URL: http://dx.doi.org/10.5539/jas.v7n2p26

\begin{abstract}
Soil moisture stress is a limiting factor in crop production particularly in arid and semi-arid lands (ASALs) as it affects many physiological and biochemical processes of plants. Research on moisture conservation measures is thus imperative. The current study used CropSyst model to simulate soil moisture under different tillage practices (oxen plough, tied ridges and furrows and ridges), cropping systems (monocropping, intercropping and crop-rotation) and organic fertilizers; farm yard manure, rock phosphate (RP) and Farmyard manure (FYM) combined with rock phosphate (RP+FYM). The study was conducted in Matuu Division, Kenya for two seasons; October 2012 to February 2013 short rain season (SRS) and March to August 2013 long rain season (LRS). The experiment was laid out in a Randomized Complete Block design with a split-split plot arrangement and replicated three times. The main plots were tillage practices whereas the split plots were cropping systems and split-split plots were organic fertilizers and a control (nothing applied). The test crops were sorghum (Sorghum bicolor L.) and sweet potato (Ipomea batatas L. lam) rotated and/or intercropped with dolichos (Lablab purpureus) and chickpea (Cicer arietinum). The CropSyst model was calibrated using measured soil texture, permanent wilting point, bulk density and initial soil moisture at the experimental site. Model validation was done using Root Mean Square Error (RMSE), percentage differences (PD) and willmott index (WI) of agreement. CropSyst model was reasonably validated as indicated by the low RMSE ( 0.5 to 1.3$)$, PD (less than \pm 15$)$ and WI index (close to 1$)$. In the first season and second season, simulated soil moisture $(101.91$ and $108.3 \mathrm{~mm})$ was significantly $(\mathrm{P}<0.05)$ high in sorghum/dolichos intercrop with RP+FYM application under tied ridges and least (13.52 and $15.4 \mathrm{~mm}$ ) in control treatment of sorghum mono crop under oxen plough. In sweet potato plots, both individual treatment and treatment interaction significantly influenced simulated soil moisture. Sweet potato-dolichos rotation (75.32 and $79.63 \mathrm{~mm}$ ), with application of RP+FYM $(75.03$ and $79.39 \mathrm{~mm})$ under tield ridges $(95$ and $100.24 \mathrm{~mm})$ had highest simulated soil moisture levels under oxen plough (32.49 and $34.36 \mathrm{~mm}$ ), sweet potato monocrop (53.46 and $55.26 \mathrm{~mm}$ ) and control $(52.52$ and $55.39 \mathrm{~mm}$ ) having the least during the first and second season, respectively. In both sorghum and sweet potato based cropping systems, soil moisture was correspondingly highest in tied ridges, intercropping and rotation systems involving dolichos and application of FYM+RP and least in control of monocropping under oxen plough. Information on effects of tillage practices, cropping systems and organic inputs could be very useful for soil water conservation purposes. Thus, using simulation models to attain the same could be the ultimate solution. A good agreement between observed and simulated soil moisture implied that CropSyst model is capable of investigating sustainable alternatives of increasing soil moisture in the ASALs.
\end{abstract}

Keywords: arid and semi-arid lands, cropping systems, CropSyst model, soil moisture

\section{Introduction}

In the arid and semi lands, plant production is limited by soil moisture availability and actual evapotranspiration (Biamah, 2005). The two parameters will influence the occurrence of water stress in rainfed agricultural systems. Fluctuations in soil moisture often have negative effects on crop productivity (Purcell et al., 2007). Moisture loss from the soil through evaporation and presence of erratic rainfall in the middle of the cropping season leads to crop failure. Rain water harvesting techniques could thus be used to improve soil moisture availability or reduce deficit 
(Gicheru et al., 2004). Information on effects of tillage practices, cropping systems and organic fertilizers that ensure effective capture and utilization of rainfall for sustainable crop production could therefore be very useful for water conservation purposes.

Behavior of agricultural systems cannot, however, be evaluated over a long period of time using field experiments due to their complexity (Grabisch, 2003). Nonetheless, dynamics of these systems can be simulated with use of decision support tools. These tools are valuable for representing long-term productivity and environmental effects on cropping systems and extrapolating the experimental results in time and space (Dillon, 1992). Crop simulation models help researchers to ascertain the relationships among environment, management and yield variability (Sinclair \& Seligman, 1996). This is in addition to predicting the effect of weather, soil properties, plant characteristics and management practices on soil moisture. Various groups use these models for decision making in agricultural systems such as efficient use of resources by providing potential plant responses to different inputs (Staggenborg et al., 2005) and hence improved efficiency of input management for cropping systems. Cropping systems simulation model represents an effort to simulate growth of single crops or crop rotations in response to weather, soil and management scenarios and provide an estimate of environmental impact (Stockle \& Nelson, 1994). One such model that has been widely used is CropSyst (Stockle et al., 1994).

CropSyst is a multi-year, multi-crop, daily time step cropping systems simulation model developed to serve as an analytical tool to study effect of climate, soils and management on cropping systems productivity and environment (Stockle et al., 1994). CropSyst simulates soil water and nitrogen budgets, crop growth and development, crop yield, residue production and decomposition, soil erosion by water and salinity (Donatelli et al., 1999). The objective of the current study was to simulate soil moisture under different tillage practices, cropping systems and organic inputs in sorghum and sweet potato based cropping systems using CropSyst model.

\section{Materials and Methods}

\subsection{Experimental Site}

The study was conducted in Matuu Division $\left(1^{\circ} 37^{\prime} \mathrm{S}\right.$ and $1^{\circ} 45^{\prime} \mathrm{S}$ latitude and $37^{\circ} 15^{\prime} \mathrm{E}$ and $37^{\circ} 23^{\prime} \mathrm{E}$ longitude and an altitude of 700-800 metres above sea level) located in Eastern province, Kenya. It falls in agro-climatic zone IV which is classified as semi-arid land (Jaetzold \& Schmidt, 2006). Rainfall patterns exhibits distinct bimodal distribution. The first rains fall between mid-March and end of May and are locally known as long rains (LR), and second rains, short rains (SR), are received between mid-October and end of December. Average seasonal rainfall is between $250-400 \mathrm{~mm}$. Interseasonal rainfall variation is large with a coefficient of variation ranging between 45-58 per cent, while temperature ranges between 17 and $24^{\circ} \mathrm{C}$.

The soils are a combination of Luvisols, Lithisols, and Ferralsols according to USDA (1978) and WRB (2006) criteria. The soils are well drained, moderately to very deep, dark reddish brown to dark yellowish brown, friable to firm, sandy clay to clay and low nutrient availability (Kibunja et al., 2010). The majority of farmers in the division are small-scale mixed farmers with low income investment for agricultural production. Crop performance and yield are significantly influenced by amount of rainfall and distribution throughout the rainy season (Macharia, 2004).

\subsection{Treatments and Experimental Design}

To obtain data for CropSyst model calibration, field experiments were conducted for two seasons; short rain season and long rain season. Data for season one was used to calibrate the model while season two data was used for model validation. The experimental layout was a Randomized Complete Block Design with a split-split plot arrangement and replicated three times. The main plots were tillage practices; Oxen plough (OP), tied ridges (TR) and, furrows and ridges (FR) whereas the split plots were cropping systems; mono cropping, intercropping and crop rotation and split-split plots were organic fertilizers; FYM, RP and FYM+RP and a control (no organic fertilizer was applied) giving a total of 60 treatments (Table 1). The test crops were sorghum and sweet potato intercropped and/or grown in rotation with legumes; Dolichos and chickpea. 
Table 1. Tillage practices, cropping systems and organic fertilizers applied during experimental period

\begin{tabular}{|c|c|c|c|c|c|c|}
\hline \multirow{2}{*}{ No. } & \multirow{2}{*}{$\begin{array}{l}\text { Tillage practice } \\
\text { (Note } 1)\end{array}$} & \multirow{2}{*}{$\begin{array}{l}\text { Cropping } \\
\text { system (Note 2) }\end{array}$} & \multirow{2}{*}{ Description } & \multirow{2}{*}{$\begin{array}{l}\text { Organic } \\
\text { fertilizer }\end{array}$} & \multicolumn{2}{|c|}{ Cropping Season } \\
\hline & & & & & LRS & SRS \\
\hline 1 & Oxen Plough & Monocropping & SOR-MONO & FYM & Sorghum & Sorghum \\
\hline 2 & & & & $\mathrm{RP}$ & Sorghum & Sorghum \\
\hline 3 & & & & $\mathrm{RP}+\mathrm{FYM}$ & Sorghum & Sorghum \\
\hline 4 & & & & Control & Sorghum & Sorghum \\
\hline 5 & & Intercropping & $\mathrm{SOR} / \mathrm{DOL}$ & FYM & Sorghum/Dolichos & Sorghum/Dolichos \\
\hline 6 & & & & $\mathrm{RP}$ & Sorghum/Dolichos & Sorghum/Dolichos \\
\hline 7 & & & & $\mathrm{RP}+\mathrm{FYM}$ & Sorghum/Dolichos & Sorghum/Dolichos \\
\hline 8 & & & & Control & Sorghum/Dolichos & Sorghum/Dolichos \\
\hline 9 & & & $\mathrm{SOR} / \mathrm{CP}$ & FYM & $\begin{array}{l}\text { Sorghum/Chick } \\
\text { pea }\end{array}$ & $\begin{array}{l}\text { Sorghum/Chick } \\
\text { pea }\end{array}$ \\
\hline 10 & & & & $\mathrm{RP}$ & $\begin{array}{l}\text { Sorghum/Chick } \\
\text { pea }\end{array}$ & $\begin{array}{l}\text { Sorghum/Chick } \\
\text { pea }\end{array}$ \\
\hline 11 & & & & $\mathrm{RP}+\mathrm{FYM}$ & $\begin{array}{l}\text { Sorghum/Chick } \\
\text { pea }\end{array}$ & $\begin{array}{l}\text { Sorghum/Chick } \\
\text { pea }\end{array}$ \\
\hline 12 & & & & Control & $\begin{array}{l}\text { Sorghum/Chick } \\
\text { pea }\end{array}$ & $\begin{array}{l}\text { Sorghum/Chick } \\
\text { pea }\end{array}$ \\
\hline 13 & & Crop Rotation & SOR-DOL & FYM & Dolichos & Sorghum \\
\hline 14 & & & & $\mathrm{RP}$ & Dolichos & Sorghum \\
\hline 15 & & & & $\mathrm{RP}+\mathrm{FYM}$ & Dolichos & Sorghum \\
\hline 16 & & & & CONTROL & Dolichos & Sorghum \\
\hline 17 & & & SOR-CP & FYM & Chickpea & Sorghum \\
\hline 18 & & & & $\mathrm{RP}$ & Chickpea & Sorghum \\
\hline 19 & & & & $\mathrm{RP}+\mathrm{FYM}$ & Chickpea & Sorghum \\
\hline 20 & & & & CONTROL & Chickpea & Sorghum \\
\hline
\end{tabular}

SOR-MONO; Sorghum monocropping, SOR/DOL; Sorghum dolichos intercrop, SOR/CP; Sorghum chickpea intercrop, SOR-DOL; Sorghum dolichos rotation, SOR-CP; Sorghum chickpea rotation, RP; Rock phosphate, FYM; farm yard manure.

\subsection{Agronomic Practices}

\subsubsection{Land Preparation and Planting}

Land was prepared manually using oxen plough and hand hoes for OP and, TR and, FR tillage practices, respectively. Planting was done in October during the short rain season of 2012 and in April during long rain season of 2013. Sorghum and sweet potato were planted during the short rains. Sorghum seeds were sown at a spacing of 30 by $60 \mathrm{~cm}$. Sweet potato cuttings were planted at a spacing of 30 by $90 \mathrm{~cm}$. Weeding was done every 4 weeks after planting. Harvesting of sorghum was done by hand after 3 months when it had reached physiological maturity while sweet potato was harvested manually using hand hoe after four months.

\subsubsection{Soil Analysis}

Initial soil sampling was done in a zigzag manner across the field using a soil auger at 0-15, 15-30 and $30-45 \mathrm{~cm}$ depths and composited into one sample per depth for physical and chemical analysis before application of treatments. Thereafter soil samples were collected at $0-15 \mathrm{~cm}$ depth during flowering and harvesting stages of sorghum and sweet potato from each treatment. Soil was analyzed for chemical properties; $\mathrm{pH}$, and mineral nitrogen and physical; soil texture, bulk density, field capacity and permanent wilting point, using standard laboratory methods (Okalebo et al., 2002). The observed soil properties were used for initial soil characterization 
and to prepare soil file used in calibrating CropSyst model. Soil moisture was determined by the gravimetric method (weight basis) and converted into volumetric proportion by multiplying with bulk density (Equation 1) and converted to volumetric water ( $\mathrm{mm}$ ) by multiplying by soil depth divided by 10 (Equation 2 ).

$$
\begin{gathered}
\text { Volumetric Water }(\%)=\text { Gravimetric Water }(\%) \times \text { Bulk Density }\left(\mathrm{g} / \mathrm{cm}^{3}\right) \\
\text { Volumetric Water }(\mathrm{mm})=\frac{\text { Volumetric } \% \times \text { Soil Test Depth }(\mathrm{cm})}{10}
\end{gathered}
$$

Bulk density was determined according to Blake and Hartage (1986). Field capacity and permanent wilting point was determined using the procedure described by Klute (1986), mineral nitrogen was determined by Kjeldahl method (Bremner \& Mulvaney, 1982).

\subsection{CropSyst Model Description}

CropSyst model is premised on assumption that actual biomass/output growth is a result of interactions involving various independent variables which include weather, soil types, management practices and crop physiology (Stockle et al. (2003), Table 1).

\begin{tabular}{|c|c|c|}
\hline File & Parameters Required by the Model & Parameters Used in the Model \\
\hline Location & Latitude, Longitude, Altitude & $\begin{array}{l}\text { Latitude: } 37^{\circ} 15^{\prime} \mathrm{E} \text { and } 37^{\circ} 23^{\prime} \mathrm{E} \\
\text { Longitude: } 1^{\circ} 37^{\prime} \mathrm{S} \text { and } 1^{\circ} 45^{\prime} \mathrm{S} \\
\text { Altitude: } 700-800 \mathrm{~m} \text { a.s.1 }\end{array}$ \\
\hline Soil & $\begin{array}{l}\text { pH, Permanent wilting point, Field capacity, Bulk density, } \\
\text { Soil texture }\end{array}$ & Table 2 (determined in the field). \\
\hline Crop & $\begin{array}{l}\text { Growing degree days (GDD) to emergence, GDD to peak } \\
\text { leaf area index, GDD to flowering, GDD to maximum grain } \\
\text { filling, GDD to maturity, Base temperatures, Cut-off } \\
\text { temperatures, maximum root depth. }\end{array}$ & $\begin{array}{l}\text { GDD were observed in the experimental site. } \\
\text { Other crop input parameters were taken as default } \\
\text { values. }\end{array}$ \\
\hline Management & $\begin{array}{l}\text { Nitrogen fertilization (application date, amount, source- } \\
\text { organic and inorganic-, and application mode- broadcast, } \\
\text { incorporated, injected). } \\
\text { Tillage operations (primary and secondary tillage } \\
\text { operations). }\end{array}$ & $\begin{array}{l}\text { Organic inputs: FYM, RP, FYM+RP, calibration was } \\
\text { done for RP which is not currently in the model. } \\
\text { Tillage practices: Tillage operations were calibrated for } \\
\text { oxen plough, tied ridges, furrows and ridges }\end{array}$ \\
\hline
\end{tabular}

Table 1. Data sets required to run CropSyst model

GDD: growing degree days; FYM: farm yard manure; RP: rock phosphate.

The model simulates soil water budget, crop canopy and root growth, dry matter production, yield, residue production and decomposition, and erosion. Management options include: cultivar selection, crop rotation, irrigation, nitrogen fertilization, tillage operations and residue management. The dates for phenological stages; emergence, flowering stage, grain filling and physiological maturity were used to calculate growing degree days $\left(G D D=T_{\text {mean }}-T_{\text {base }}\right.$; where $\left.T_{\text {mean }}=\left(T_{\max }+T_{\min }\right) / 2\right)$. Location file was also prepared using observed weather data from nearest weather station. For each tillage practices, management files were prepared to represent each cropping systems and organic inputs. Soil moisture measurements were used for model calibration. The values of crop input parameters (maximum harvest index, maximum expected LAI, base temperature, cut-off temperature and maximum root depth) were obtained from the CropSyst manual (Stockle et al., 2003).

\subsection{CropSyst model Calibration}

The calibrated values (Table 2) were permanent wilting point, field capacity and mineral nitrogen. Observed mineral nitrogen was adjusted from $24 \mathrm{Kg} \mathrm{N} \mathrm{ha}^{-1}$ to $58.91 \mathrm{Kg} \mathrm{N} \mathrm{ha}^{-1}$, permanent wilting point was adjusted from $0.17 \mathrm{~m}^{3} / \mathrm{m}^{3}$ to $0.29 \mathrm{~m}^{3} / \mathrm{m}^{3}$ while field capacity was also adjusted from $0.23 \mathrm{~m}^{3} / \mathrm{m}^{3}$ to $0.38 \mathrm{~m}^{3} / \mathrm{m}^{3}$ to ensure closeness between observed and simulated soil moisture values. The values were adjusted by comparing observed soil water content with model output. Calibrated values ensured closeness between observed soil water values and simulated values. Crop growth was majorly affected by soil moisture and nitrogen content and adjustment to the required 
amount was accordingly done. Soil texture and bulk density were not calibrated since they were within the CropSyst required range.

Table 2. Observed and calibrated physic-chemical soil properties

\begin{tabular}{|c|c|c|c|c|c|c|}
\hline \multirow{2}{*}{$\begin{array}{l}\text { Soil properties } \\
\text { Depth }(\mathrm{cm})\end{array}$} & \multicolumn{3}{|c|}{ Observed soil properties/Depth $(\mathrm{cm})$} & \multicolumn{3}{|c|}{ Calibrated soil properties/Depth $(\mathrm{cm})$} \\
\hline & 0-10 & $10-20$ & 20-30 & 0-10 & $10-20$ & 20-30 \\
\hline Sand $(\%)$ & 49.32 & 49.30 & 49.36 & 49.32 & 49.30 & 49.36 \\
\hline Silt (\%) & 38.88 & 38.97 & 38.77 & 38.88 & 38.97 & 38.77 \\
\hline Clay $(\%$ & 11.8 & 11.71 & 11.78 & 11.8 & 11.71 & 11.78 \\
\hline Textural class & \multicolumn{6}{|c|}{ Sand-Clay (USDA Classification) } \\
\hline $\mathrm{pH}\left(\mathrm{H}_{2} \mathrm{O}\right)$ & 6.5 & 6.7 & 6.8 & 6.5 & 6.7 & 6.8 \\
\hline Permanent wilting point $\left(\mathrm{m}^{3} / \mathrm{m}^{3}\right)$ & 0.17 & 0.18 & 0.20 & 0.27 & 0.28 & 0.29 \\
\hline Field capacity $\left(\mathrm{m}^{3} / \mathrm{m}^{3}\right)$ & 0.23 & 0.25 & 0.27 & 0.34 & 0.36 & 0.38 \\
\hline Bulk density $\left(\mathrm{g} \mathrm{cm}^{-3}\right)$ & 1.503 & 1.508 & 1.67 & 1.503 & 1.508 & 1.67 \\
\hline $\mathrm{NH}_{4}-\mathrm{N}\left(\mathrm{Kg} \mathrm{N} \mathrm{ha}^{-1}\right)$ & 28.54 & 27.02 & 34.76 & 58.91 & 57.39 & 55.46 \\
\hline $\mathrm{NO}_{3}--\mathrm{N}\left(\mathrm{Kg} \mathrm{N} \mathrm{ha}^{-1}\right)$ & 24.87 & 29.34 & 25.72 & 52.67 & 51.83 & 50.44 \\
\hline
\end{tabular}

\subsection{Model Validation}

CropSyst was validated by comparing model outputs withobserved soil moisture in different tillage practices, cropping systems and organic inputs. The agreement between model and reality was verified by means of percentage differences (PD) and root mean square error (RMSE). This is frequently used measure of the difference between values simulated by a model and those actually observed from the experiment that is being modelled (Equation 3).

$$
\text { RMSE }=\left[\mathrm{n}^{-1} \sum\left(\text { Yield }_{\text {meas }}-\text { Yieldpred }\right)^{2}\right]
$$

Additionally, Willmott index (WI) of agreement was calculated, which take a value between 0.0 and 1.0; where 1.0 means perfect fit (Willmott, 1981).

\subsection{Simulations}

The input files required by CropSyst model for Matuu Division, sorghum and sweet potato crops were used to run the model. Planting dates were set as $10^{\text {th }}$ October, 2012 for both crops. Simulations were run from $10^{\text {th }}$, September, 2012 a month before planting and ended in $31^{\text {st }}$, March 2013 for sorghum and $31^{\text {st }}$ May for sweet potato. The experiment was repeated for the second season in 2013. The starting and ending dates indicated simulation period. Sweet potato required more time to mature compared to sorghum and hence the difference in ending simulation date. Soil moisture was simulated by specifying the soil, location, crop and management practices (Table 1).

\subsection{Statistical Test}

Effect of different treatments on soil moisture were statistically evaluated by analysis of variance (ANOVA) as a split-split plot design (Genstat 14.0 for Windows). Least Significant Differences (LSD) at the 5\% level were used to detect differences among means.

\section{Results and Discussion}

\subsection{Validation of CropSyst Model for Soil Moisture ( $\mathrm{mm}$ ) in Sorghum and Sweet Potato Cropping Systems.}

Sorghum cropping systems: Simulated soil moisture showed low values of RMSE and percentage differences (PD) compared to observed moisture in the sorghum cropping system. The PD (range -3.43 to +7.04), RMSE (0.582) and a willmott index of agreement (WI) of 0.989 between observed and simulated values in all cropping systems with application of FYM under oxen plough were indicative of good model performance. In all cropping systems with combined application of FYM and RP under furrows and ridges, the PD ranged from -3.128 to +6.203 with RMSE and WI of 0.512 and 0.974 , respectively. For RP application, across all cropping systems and tillage practices, the PD ranged from -2.002 to +4.661 while the RMSE and WI were correspondingly 0.487 and 
0.999. In the control, the PD ranged from -0.184 to +6.123 with RMSE of 0.884 and WI of 0.907 (Table 3 ).

The PD under furrows and ridges, for all cropping systems with FYM application ranged from -3.73 to +2.57 while the RMSE was 0.682 and a WI of 0.995 . When FYM+RP was applied, the PD ranged from -3.73 to +2.57 with RMSE of 0.872 and WI of 0.993 . With application of RP, the PD ranged from -1.51 to +4.994 with a RMSE of 0.685 and WI of 0.957. In the control, the PD ranged from -2.96 to +8.67 with a RMSE of 0.895 and WI of 0.987 (Table 3).

Under tied ridges, for all cropping systems with application of FYM, the PD between observed and simulated values ranged from -1.39 to 3.58 while the RMSE was 0.8286 and WI of 0.955 . For the FYM+RP treatment, the PD ranged from -1.633 to +3.078 with RMSE of 0.885 and WI of 0.952 . For RP, across all cropping systems and tillage practices, the PD ranged from -1.66 to +0.244 with a RMSE of 0.624 and WI of 0.925 . In the control, the PD ranged from -1.05 to +1.55 with a RMSE of 0.687 and WI of 0.972 (Table 3 ).

The PD between observed and simulated values were less than $9 \%$ implying closeness between observed and simulated values. Stockle et al. (2003) noted that simulation models can over-or under-estimate observed values by \pm 27 percent, without necessarily undermining reasonability of estimates obtained. All the simulated yields were therefore within what can be termed as reasonable estimate of the actual soil moisture.

The low values of RMSE indicate that CropSyst model reasonably simulated soil moisture for different cropping systems, tillage practices and organic inputs. Higher WI values for soil moisture indicate that the model simulated soil moisture reasonably well. CropSyst model has also been reported to simulate soil moisture to a reasonable range as stated by Baroudy et al. (2012) who found an RMSE of $2.5 \mathrm{~mm}$ and $2.23 \mathrm{~mm}$ and a WI of 0.98 and 0.96 while determining soil water for two growing seasons. Similarly Benli et al. (2007) obtained a high WI of agreement with a value of 0.98 and attributed this to agreement between observed and simulated soil moisture values. 
Table 3. Statistical comparisons of observed and simulated soil moisture ( $\mathrm{mm}$ ) under different tillage practices, cropping systems and organic fertilizers during sorghum growing season

\begin{tabular}{|c|c|c|c|c|c|c|c|c|c|c|c|c|}
\hline \multirow{2}{*}{ Treatments } & \multicolumn{3}{|c|}{ FYM } & \multicolumn{3}{|c|}{ FYM+RP } & \multicolumn{3}{|c|}{$\mathbf{R P}$} & \multicolumn{3}{|c|}{ Control } \\
\hline & Observed & Simulated & $\mathrm{PD}(\%)$ & Observed & Simulated & $\mathrm{PD}(\%)$ & Observed & Simulated & $\mathrm{PD}(\%)$ & Observed & Simulated & $\mathrm{PD}(\%)$ \\
\hline \multicolumn{13}{|l|}{ Oxen plough } \\
\hline SOR-MONO & 21.913 & 20.82 & +0.049 & 19.5 & 20.11 & -3.128 & 18.1 & 17.92 & +0.994 & 14.203 & 16.816 & -0.184 \\
\hline SOR/DOL & 49.35 & 49.00 & +0.717 & 56.9 & 57.38 & -0.844 & 60.9 & 59.32 & +2.59 & 46.886 & 44.887 & +4.24 \\
\hline $\mathrm{SOR} / \mathrm{CP}$ & 46.97 & 46.41 & +7.04 & 57.13 & 56.48 & +1.138 & 60.88 & 61.22 & -0.558 & 37.558 & 43.41 & +4.947 \\
\hline SOR-DOL & 40.64 & 40.88 & +3.83 & 17.41 & 16.33 & +6.203 & 25.31 & 24.31 & +4.661 & 32.515 & 33.367 & +1.88 \\
\hline SOR-CP & 33.845 & 35.68 & -3.43 & 44.43 & 45.75 & -2.566 & 38.97 & 39.57 & -2.002 & 28.317 & 25.583 & +6.123 \\
\hline RMSE & & 0.582 & & & 0.512 & & & 0.487 & & & 0.884 & \\
\hline WI & & 0.989 & & & 0.974 & & & 0.999 & & & 0.907 & \\
\hline \multicolumn{13}{|c|}{ Furrows and ridges } \\
\hline SOR-MONO & 36.53 & 35.59 & +2.57 & 43.05 & 40.9 & +4.994 & 38.75 & 36.84 & +4.929 & 29.224 & 26.69 & +8.67 \\
\hline SOR/DOL & 79.89 & 80.84 & -1.19 & 94.16 & 94.87 & -0.754 & 84.47 & 86.02 & -1.510 & 63.914 & 63.34 & +0.9 \\
\hline $\mathrm{SOR} / \mathrm{CP}$ & 60.126 & 62.37 & -3.73 & 70.68 & 69.62 & +1.749 & 63.87 & 64.83 & -0.941 & 48.101 & 47.25 & +1.77 \\
\hline SOR-DOL & 84.755 & 84.51 & +0.29 & 78.47 & 77.52 & +1.549 & 89.09 & 88.80 & +1.224 & 67.804 & 69.19 & -2.96 \\
\hline SOR-CP & 66.817 & 66.51 & +0.524 & 93.04 & 94.85 & -1.9454 & 70.82 & 71.31 & -0.607 & 53.454 & 51.83 & +3.03 \\
\hline RMSE & & 0.682 & & & 0.872 & & & 0.685 & & & 0.895 & \\
\hline WI & & 0.995 & & & 0.993 & & & 0.957 & & & 0.987 & \\
\hline \multicolumn{13}{|l|}{ Tied Ridges } \\
\hline SOR-MONO & 76.94 & 78.00 & -1.39 & 87.17 & 85.01 & +3.078 & 84.31 & 85.71 & -1.66 & 72.8 & 70.72 & +1.03 \\
\hline SOR/DOL & 93.77 & 93.62 & +0.16 & 90.21 & 89.27 & +1.072 & 93.02 & 94.12 & -1.279 & 89.90 & 88.51 & +1.55 \\
\hline $\mathrm{SOR} / \mathrm{CP}$ & 75.83 & 73.11 & +3.56 & 86.32 & 87.03 & -0.787 & 89.12 & 90.21 & -1.369 & 72.75 & 73.00 & -0.35 \\
\hline SOR-DOL & 83.72 & 83.10 & +0.749 & 85.01 & 86.42 & -1.633 & 90.05 & 89.83 & +0.244 & 80.55 & 81.39 & -1.05 \\
\hline SOR-CP & 88.38 & 87.21 & +1.319 & 93.7 & 92.56 & +1.235 & 96.08 & 97.05 & -0.109 & 87.45 & 87.21 & +0.48 \\
\hline RMSE & & 0.8286 & & & 0.885 & & & 0.624 & & & 0.687 & \\
\hline WI & & 0.955 & & & 0.952 & & & 0.925 & & & 0.972 & \\
\hline
\end{tabular}

SOR-MONO: Sorghum monocropping; SOR/DOL: Sorghum dolichos intercrop; SOR/CP: Sorghum chickpea intercrop; SOR-DOL: Sorghum dolichos rotation; SOR-CP: Sorghum chickpea rotation; RP: Rock phosphate; FYM: farm yard manure; PD: Percentage differences; RMSE: root mean square error; WI: willmott index.

\subsection{Sweet Potato Cropping Systems}

The PD ranged from -7.2 to $+12.09,-5.003$ to $+7.539,4.538$ to +8.1 and -6.7 to +6.3 , RMSE $(1.323,1.012$, 0.973 and 0.753$)$ and WI $(0.906,0.966,0.953$ and 0.946$)$ with application of FYM, RP, FYM+RP and control, respectively for all cropping systems under oxen plough (Table 4) showed good agreement between observed and simulated values of soil moisture. For all cropping systems, under furrows and ridges, when FYM was applied, PD ranged from -4.3 to +2.8 with RMSE of 0.687 and WI of 0.996 , for RP, the PD ranged from -3.548 to +4.217 with RMSE of 1.155 and WI of 0.986 while in control PD ranged from -5.8 to +2.6 with RMSE of 0.699 and WI of 0.997 (Table 4).

In all cropping systems under tied ridges the PD ranged from -3.4 to +3.6 with RMSE of 1.249 and WI of 0.739 with FYM application, For the FYM+RP treatments, the PD ranged from -1.902 to +1.788 with RMSE of 0.878 and WI of 0.832 , in RP treatment, the PD ranged from -0.815 to +1.888 with RMSE of 0.693 and WI of 0.831 while in control the PD ranged from -3.7 to +3.9 with RMSE of 1.083 and WI of 0.889 (Table 4).

The PD between observed and simulated values for soil moisture in different tillage practices, cropping system and organic inputs were less than $\pm 13 \%$ indicating closeness between measured and simulated values. Low PD between observed and simulated values shows good agreement. According to Brassard and Singh (2007), a 
difference between observed and simulated values of up to $\pm 15 \%$ was judged acceptable since there is closeness between the two values.

Tingem et al. (2008) also found a percentage difference between observed and simulated values ranging from 0.6 to -4.5 which are in close agreement with current results. Singh et al. (2008) found CropSyst to predict soil moisture well with low RMSE values.

Table 4. Statistical comparisons of observed and simulated soil moisture $(\mathrm{mm})$ under different tillage practices, cropping systems and organic fertilizers during sweet potato growing season

\begin{tabular}{|c|c|c|c|c|c|c|c|c|c|c|c|c|}
\hline \multirow{2}{*}{ Treatments } & \multicolumn{3}{|c|}{ FYM } & \multicolumn{3}{|c|}{ FYM+RP } & \multicolumn{3}{|c|}{$\mathbf{R P}$} & \multicolumn{3}{|c|}{ Control } \\
\hline & Observed & Simulated & PC (\%) & Observed & Simulated & PC (\%) & Observed & Simulated & PC (\%) & Observed & Simulated & PC (\%) \\
\hline \multicolumn{13}{|l|}{ Oxen plough } \\
\hline SP-MONO & 31.13 & 27.37 & +12.1 & 28.68 & 27.41 & +4.428 & 26.44 & 25.31 & +4.274 & 20.75 & 21.72 & -5.6 \\
\hline SP/DOL & 30.98 & 30.39 & +2.0 & 37.90 & 35.98 & +5.066 & 34.11 & 32.88 & +3.606 & 24.79 & 26.24 & -6.0 \\
\hline $\mathrm{SP} / \mathrm{CP}$ & 25.01 & 26.46 & -6.0 & 30.58 & 32.11 & -5.003 & 27.53 & 25.30 & +8.100 & 20.00 & 18.73 & +6.3 \\
\hline SP-DOL & 42.43 & 45.48 & -7.2 & 49.46 & 50.76 & -2.628 & 44.51 & 46.53 & -4.538 & 32.68 & 34.32 & -5.0 \\
\hline SP-CP & 20.17 & 20.76 & -2.9 & 24.67 & 22.81 & +7.539 & 22.20 & 20.66 & +6.937 & 16.13 & 17.21 & -6.7 \\
\hline RMSE & & 1.323 & & & 1.012 & & & 0.973 & & & 0.753 & \\
\hline WI & & 0.906 & & & 0.966 & & & 0.953 & & & 0.946 & \\
\hline \multicolumn{13}{|c|}{ Furrows and ridges } \\
\hline SP-MONO & 41.16 & 42.93 & -4.3 & 48.86 & 50.13 & -2.599 & 43.97 & 45.53 & -3.548 & 32.93 & 34.85 & -5.8 \\
\hline $\mathrm{SP} / \mathrm{DOL}$ & 58.64 & 57.03 & +2.8 & 69.62 & 67.87 & +2.514 & 62.66 & 64.64 & -3.548 & 46.91 & 46.02 & +1.9 \\
\hline $\mathrm{SP} / \mathrm{CP}$ & 43.49 & 43.81 & -0.7 & 51.63 & 50.20 & +3.769 & 46.47 & 44.51 & +4.217 & 34.79 & 33.88 & +2.6 \\
\hline SP-DOL & 94.42 & 75.54 & -1.3 & 82.53 & 80.35 & +2.642 & 81.22 & 83.79 & -3.164 & 95.66 & 74.57 & +1.3 \\
\hline SP-CP & 84.97 & 84.98 & -2.4 & 87.55 & 89.52 & -2.250 & 85.79 & 84.03 & +2.052 & 67.97 & 68.88 & -1.3 \\
\hline RMSE & & 0.687 & & & 1.011 & & & 1.153 & & & 0.699 & \\
\hline WI & & 0.996 & & & 0.987 & & & 0.986 & & & 0.997 & \\
\hline \multicolumn{13}{|l|}{ Tied Ridges } \\
\hline SP-MONO & 84.19 & 87.18 & -1.1 & 90.10 & 91.76 & -1.842 & 88.38 & 86.89 & +1.685 & 82.07 & 80.98 & -3.7 \\
\hline SP/DOL & 87.51 & 87.97 & -3.4 & 91.17 & 89.91 & +1.382 & 84.90 & 83.76 & +1.343 & 83.95 & 85.71 & -3.3 \\
\hline $\mathrm{SP} / \mathrm{CP}$ & 82.93 & 79.92 & +3.6 & 90.04 & 88.43 & +1.788 & 87.38 & 85.73 & +1.888 & 71.68 & 74.47 & +3.9 \\
\hline SP-DOL & 86.85 & 85.71 & +1.6 & 94.11 & 95.90 & -1.902 & 84.70 & 85.39 & -0.815 & 69.48 & 70.33 & -1.2 \\
\hline SP-CP & 95.10 & 93.12 & +2.1 & 96.41 & 95.23 & +1.223 & 92.75 & 93.45 & -0.755 & 76.08 & 78.27 & -2.9 \\
\hline RMSE & & 1.249 & & & 0.878 & & & 0.693 & & & 1.083 & \\
\hline WI & & 0.739 & & & 0.832 & & & 0.831 & & & 0.889 & \\
\hline
\end{tabular}

SP-MONO: Sweet potato monocropping; SP/DOL: Sweet potato dolichos intercrop; SP/CP: Sweet potato chickpea intercrop; SP-DOL: Sweet potato dolichos rotation; SOR-CP: Sweet potato chickpea rotation; RP: Rock phosphate; FYM: Farm yard manure; PD: Percentage differences; RMSE: root mean square error; WI: willmott index of agreement.

\subsection{Simulated Soil Moisture in Sorghum and Sweet Potato Cropping Systems}

Sorghum cropping system: There were significant $(\mathrm{P}<0.05)$ differences in tillage practices, cropping systems and organic inputs across seasons. There were also significant interaction $(\mathrm{P}<0.05)$ effects between tillage practices with cropping systems, tillage practices with organic input and tillage practice with cropping systems and organic inputs.

In the first season, simulated soil moisture $(101.91 \mathrm{~mm})$ was significantly $(\mathrm{P}<0.05)$ high in interactions 
interactions involving tied ridges and sorghum/dolichos intercrop when RP+FYM were applied (Figure 1). Simulated soil moisture $(13.52 \mathrm{~mm})$ was lowest in sorghum mono crop with no organic input applied under oxen plough (Figure 1).

In the second season, simulated soil moisture was significantly high (108.3 $\mathrm{mm})$ in sorghum/dolichos intercropping with application of FYM+RP under tied ridges (Figure 2). Lowest simulated soil moisture (15.4 $\mathrm{mm}$ ) was observed in the interaction between oxen plough and sorghum monocropping with no organic input applied (Figure 2).

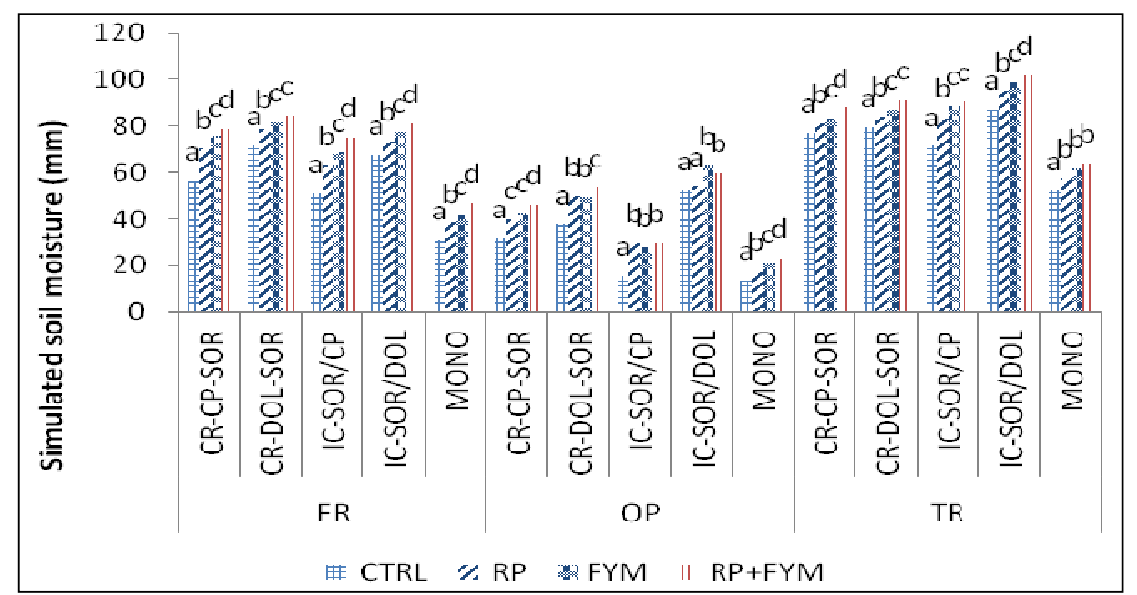

Figure 1. Simulated soil moisture ( $\mathrm{mm}$ ) across tillage practices, cropping systems and organic fertilizers in season 1

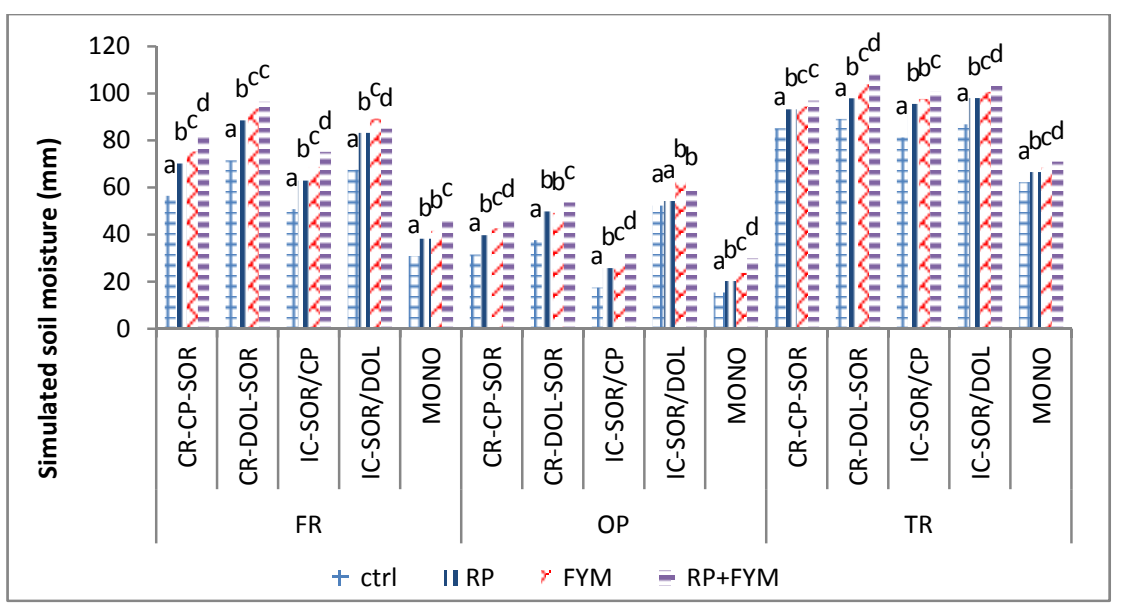

Figure 2. Simulated soil moisture (mm) across tillage practices, cropping systems and organic fertilizers in season 2

The interaction effects between tied ridges, sorghum in rotation with dolichos and FYM+ RP on soil moisture could be attributed to reduced run-off and increased infiltration due to micro- catchment formed by the tied ridges. Sorghum intercropped with dolichos had significantly high soil moisture which could be attributed to reduced evaporation due to dense soil cover provided by the two crops. Higher soil moisture in the FYM+RP could be attributed to improved water retention by the two organic fertilizers.

According to Guzha (2004), tillage practices that increase soil roughness such as tied ridging and ripping can increase soil water storage and availability to crop because they are able to capture rainfall and increase the time for infiltration to take place. Rockstrom (2013) stated that intercropping increases canopy cover and thus reducing evaporation from soil surface. Palm et al. (1997) similarly reported improved soil physical properties such as infiltration and soil moisture retention with application of FYM+RP. 
Sweet potato cropping systems: There were significant $(\mathrm{P}<0.05)$ difference in soil moisture in the different tillage practices, cropping systems and organic inputs. Interactions between tillage practice and cropping systems, tillage practice and organic inputs also had significant $(\mathrm{P}<0.05)$ effect.

Tillage practices: In the first season, simulated soil moisture $(95 \mathrm{~mm})$ was significantly higher in tied ridges followed by furrows and ridges $(68.44 \mathrm{~mm})$ and least $(32.49 \mathrm{~mm})$ in oxen plough. In the second season, simulated soil moisture $(100.24 \mathrm{~mm})$ was significantly highr in tied ridges followed by furrows and ridges (72.4 $\mathrm{mm})$ and least $(34.36 \mathrm{~mm})$ in oxen plough (Figure 3).

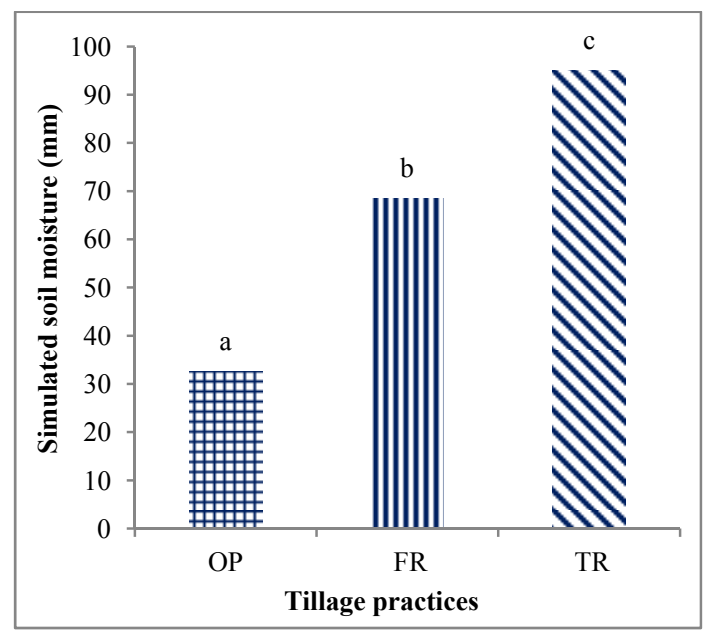

Season 1

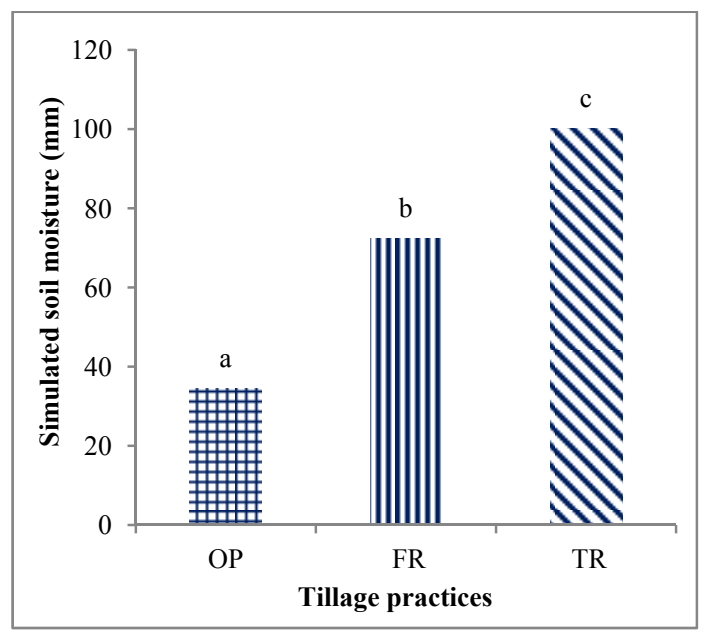

Season 2

Figure 3. Simulated soil moisture in the different tillage practices

OP: oxen plough; FR: furrows and ridges; TR: tied ridges.

Tied ridges are able to capture more water compared to oxen ploughed plots and furrows and ridges. The more water collected in tied ridges could be attributed to reduced runoff. According to Taye and Abera (2010), in tied ridges, furrows are blocked with earth ties creating basins that catch and hold rainwater, minimizing surface runoff and improving downward infiltration of water. Tillage can improve the physical and hydro-physical properties of the soil and consequently increase rain water harvesting and crop yields (Gachene \& Kimaru, 2003; Strudley et al., 2008).

Cropping systems: In the first season, simulated soil moisture $(75.32 \mathrm{~mm})$ was significantly $(\mathrm{P}<0.05)$ high when sweet potato was rotated with dolichos and least (53.46) in the sweet potato monocrop. Simulated soil moisture $(79.63 \mathrm{~mm})$ in the second season was highest $(55.26 \mathrm{~mm})$ in sweet potato-dolichos rotation and least on sweet potato mono crop (Figure 4). 


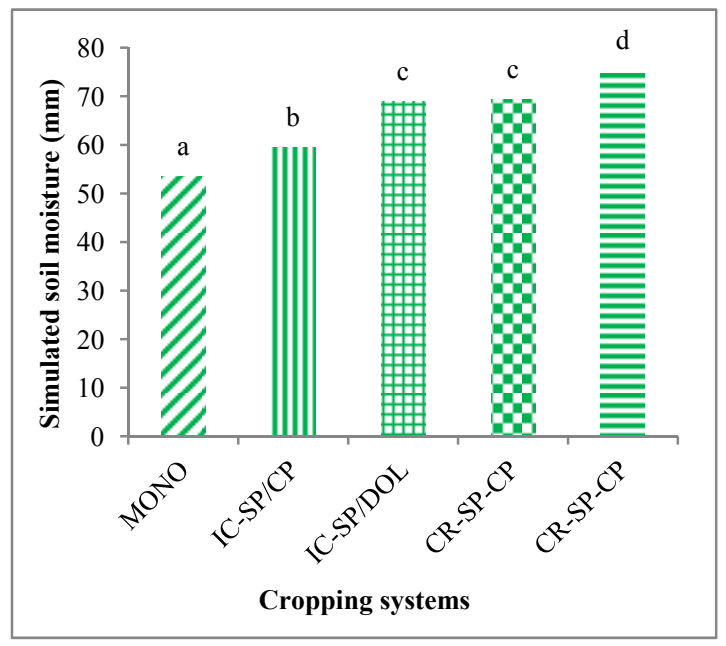

Season 1

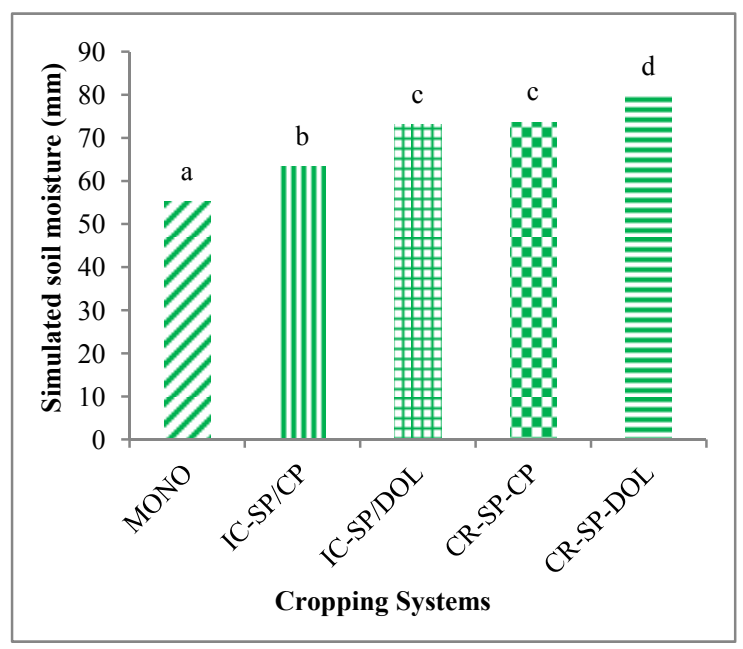

Season 2

Figure 4. Simulated soil moisture in the different cropping systems

IC: intercropping; CR: crop rotation; SP: sweet potato; CP: chickpea; DOL: dolichos.

Higher simulated soil moisture in sweet potato- dolichos rotation could be attributed to increased water availability since sweet potato and dolichos had different rooting systems which increased water availability in soil through expanded soil depth. According to Roder (1989) rotation of legumes and cereals, with their different root systems optimizes the network of root channels in soil to deeper soil depths. This leads to increased water penetration, water- holding capacity and available water for crop use.

Organic inputs: Simulated soil moisture $(75.03 \mathrm{~mm})$ in the first season was significantly high when RP+FYM was applied and least $(52.52 \mathrm{~mm})$ in the control (Figure 5). In the scond season, simulated soil moisture (79.39 $\mathrm{mm}$ ) was highest in RP+FYM and least $(55.39 \mathrm{~mm}$ ) in the control (Figure 5).

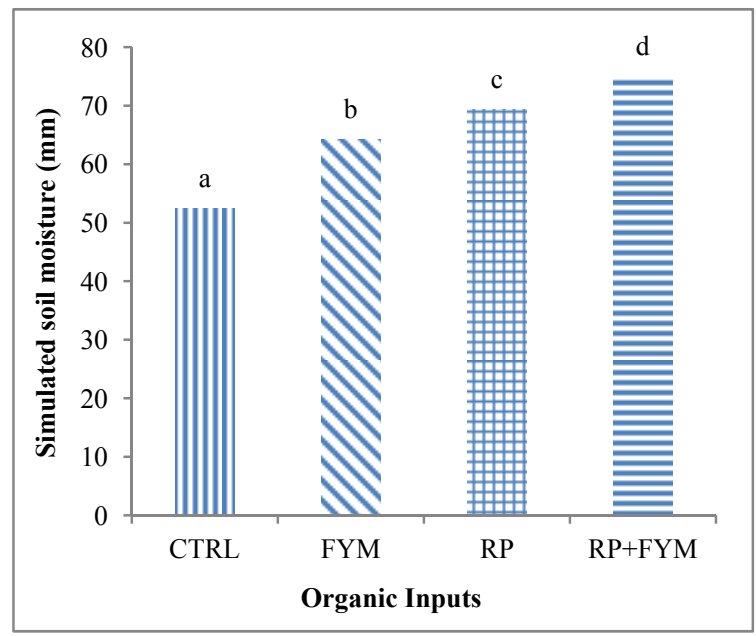

Season 1

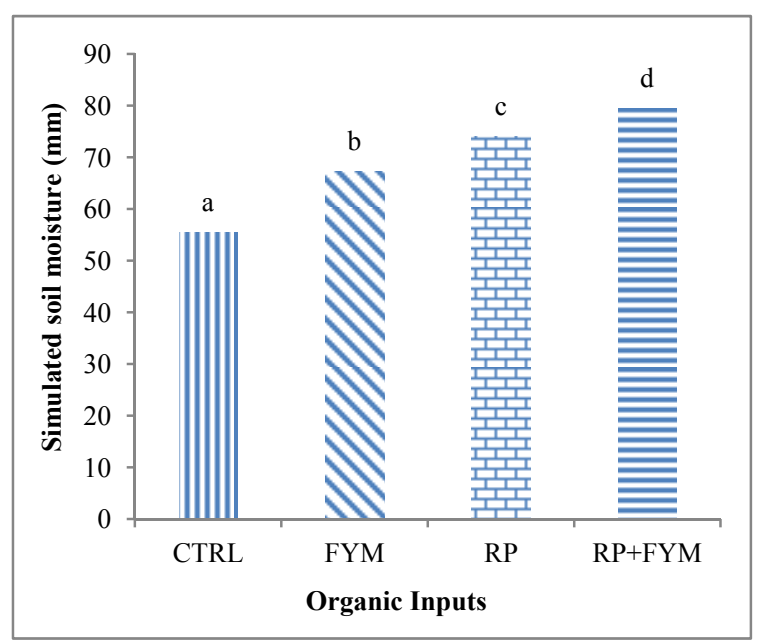

Season 2

Figure 5. Simulated soil moisture in the different organic inputs

CTRL: control; FYM: farm yard manure; RP: rock phosphate.

The FYM+RP had high soil moisture and this could be due to improvement of soil structure and hence increased soil water holding capacity. FYM+RP could have improved the soil physical properties particularly water infiltration rate. Lal (1997) and Sharif et al. (2013) also reported that FYM+RP application improves water 
infiltration rate, water holding capacity, soil aeration and soil moisture.

Tillage practices and cropping systems interaction: In the first season simulated soil moisture $(108.08 \mathrm{~mm}) \mathrm{was}$ significantly $(\mathrm{P}<0.05)$ higher in the interaction between tied ridges and sweet potato intercropped with dolichos and least $(23.16 \mathrm{~mm})$ in the interaction between oxen plough and sweet potato mono crop (Figure 6). In the second season, simulated soil moisture $(114.48 \mathrm{~mm})$ was significantly high in the interaction between tied ridges and sweet potato intercropped with dolichos and least $(25.87 \mathrm{~mm})$ in the interaction between oxen plough and sweet potato monocrop (Figure 6).
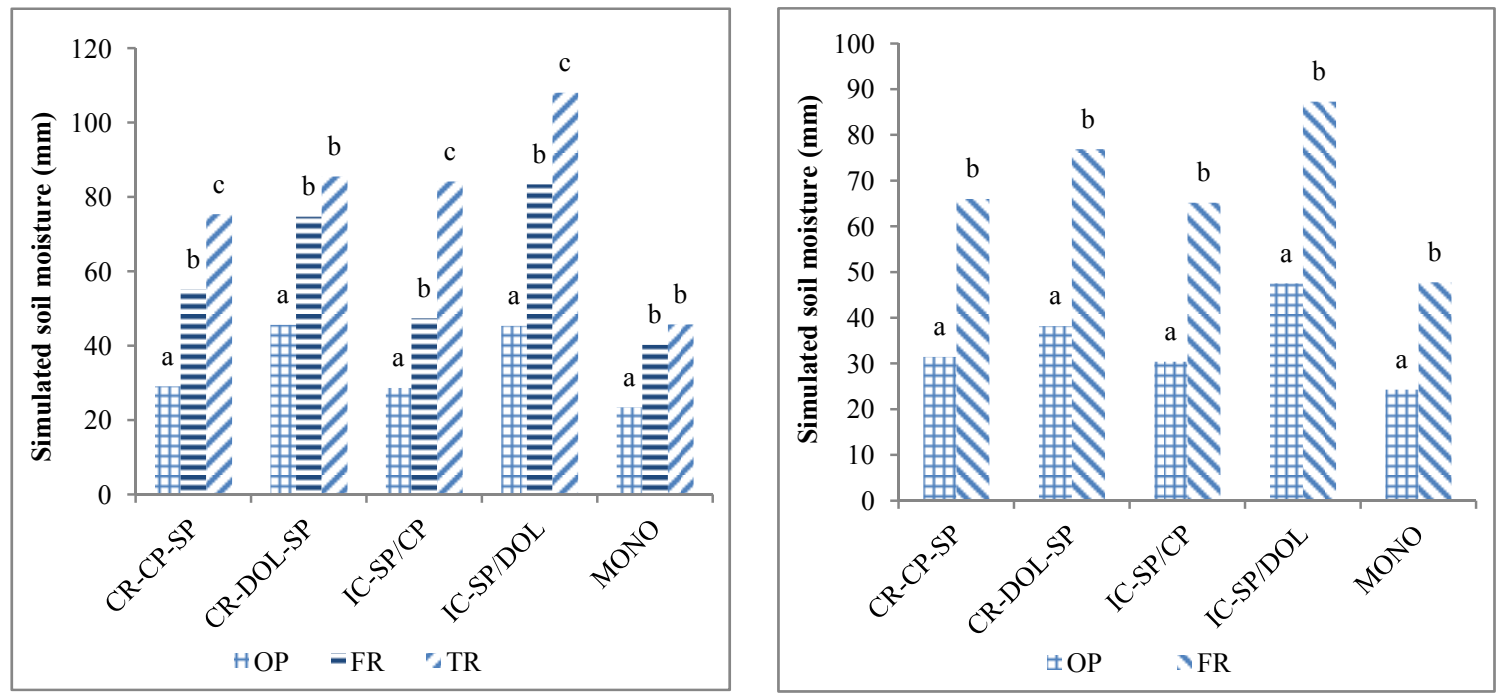

Figure 6. Simulated soil moisture in the interaction between tillage practices and cropping systems

CR; Crop Rotation, IC; Intercropping, CP; chickpea, SP; sweet potato, DOL; dolichos, OP; oxen plough, FR; Furrows and Ridges, TR; Tied Ridges

High simulated soil moisture in tied ridges and sweet potato intercropping could be attributed to reduced run off and reduced evaporation rate as a result of dense canopy created by the two crops. High plant densities in intercropping together with litter-fall block water flow while increased volume of roots further opens up the soil hence improved infiltration. According to Zougmore et al. (2000), intercropping allows for formation of a thick canopy due to higher planting densities. The dense canopy formed helps prevent soil erosion by rain water action. Fewer rain drops reach the soil surface with great impact because the dense canopy intercepts and break-up heavy rain drops. The FYM+RP application had high soil moisture due to improvement of soil structure and this may have led to increased water holding capacity.

Tillage practices and organic input interaction: In the first season, simulated soil moisture $(108.57 \mathrm{~mm})$ was significantly higher in interaction between tied ridges and RP+FYM and least $(25.77 \mathrm{~mm})$ in the interaction between oxen plough and control. In the second season, simulated soil moisture $(112.69 \mathrm{~mm})$ was highest in the interaction between tied ridges and RP+FYM and least $(27.43 \mathrm{~mm})$ in the interaction between oxen plough and control (Figure 7). 


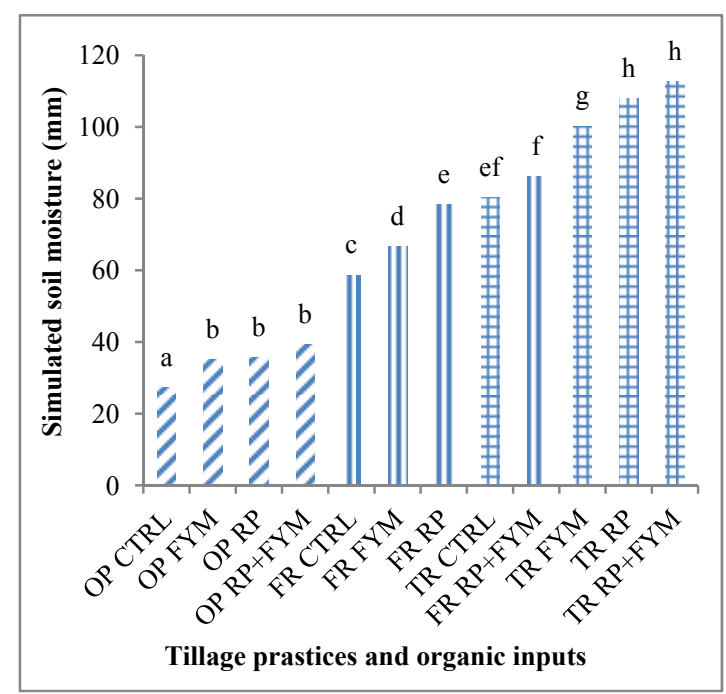

Season 1

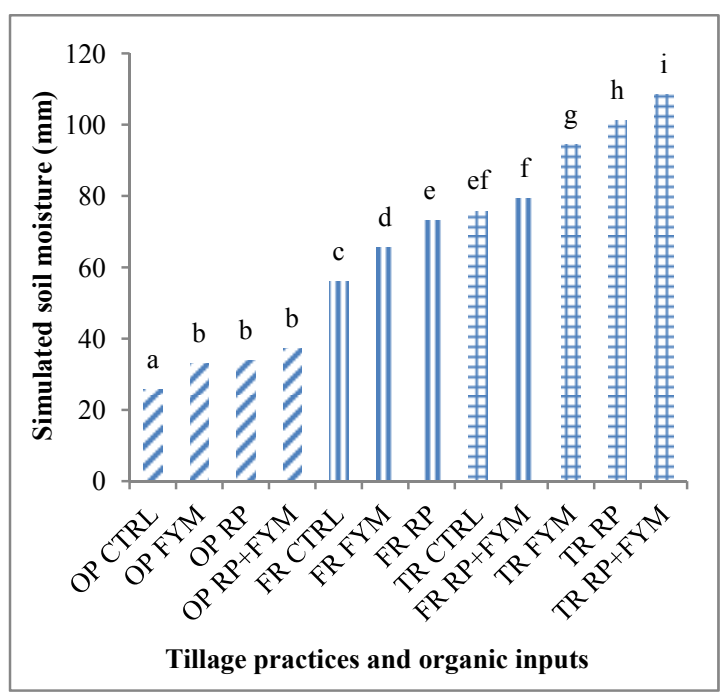

Season 2

Figure 7. Simulated soil moisture in the interaction between tillage practices with organic input

OP: oxen plough; FR: furrows and ridges; TR: tied ridges; CTRL: control; FYM: farm yard manure; RP: rock phosphate.

High soil moisture in tied ridges and FYM+RP could be attributed to the fact that tied ridges allow rainwater to be retained on open furrows for longer duration as water infiltrates into soil. This soil management techniques favour prolonged rainwater infiltration and retention thus raising overall soil moisture retention and soil water holding capacity. According to Itabari et al. (2003) tied ridges increase rainwater retention thus increased soil moisture. Combined FYM and RP could have increased water retention in the soil. Manure and rock phosphate have similarly been reported to increase water retention and availability in soil (Silva et al., 2006).

\section{Conclusion}

In sorghum and sweet potato based cropping systems, simulated soil moisture was highest in tied ridges, intercropping and rotation systems when FYM+RP was applied and least in oxen plough, monocropping when no organic fertilizer was applied. In sorghum based cropping system, soil moisture was high in the interactions involving tied ridges and sorghum intercropped with dolichos when FYM+RP were applied. Whereas in the sweet potato based cropping system, highest soil moisture was observed in interactions involving tied ridges with sweet potato intercropped with dolichos when FYM+RP were applied.

Information on the effects of tillage practices, cropping systems and organic fertilizers could therefore be very useful for water soil conservation purposes. Thus, using simulation models to attain that could be ultimate solution. A good agreement between observed and simulated soil moisture implied that the CropSyst model was capable of investigating sustainable alternatives of increasing soil moisture.

\section{Acknowledgements}

The authors appreciate the McKnight Foundation for providing funds to first author to carry out the study which forms part of her master's thesis. We would also like to appreciate the farmers of Matuu division for availing their farms for field research and their willingness to work with us.

\section{References}

Anderson, J. M., \& Ingram, J. S. (1993). Tropical Soil Biology and Fertility: A Handbook of Methods. CAB International, Wallingford, UK.

Benli, B., Pala, M., Stockle, C., \& Oweis, T. (2007). Assessment of winter wheat production under early sowing with supplemental irrigation in a cold highland environment using CropSyst simulation model. Agric. Water Mang., 3, 45-54. http://dx.doi.org/10.1016/j.agwat.2007.06.014

Biamah, E. K. (2005). Coping with drought: Options for soil and water management in semi arid Kenya. Tropical resource management papers No. 58. Wageningen University and research centre publication. 
Biamah, E. K., Stroosnijder, L., Sharma, T. C., \& Cherogony, R. K. (1998). Effects of conservation tillage on watershed hydrology in semi-arid Kenya: An application of AGNPS, SCS-CN and Rational Formula runoff models (Vol. 3, pp. 335-357).

Blake, G. R., \& Hartge, K. H. (1986a). Bulk Density. In A. Klute (Ed.), Methods of Soil Analysis. Part 1 Physical and Mineralogical Methods (2nd ed.). American Society of Agronomy, Madison WI.

Blake, G. R., \& Hartge, K. H. (1986b). Particle Density. In A. Klute (Ed.), Methods of Soil Analysis. Part 1 Physical and Mineralogical Methods (2nd ed.). American Society of Agronomy, Madison WI.

Brassard, J. P., \& Singh, B. (2007). Assessing the impacts of and climate change and $\mathrm{CO}_{2}$ increase on potential crop yields in Southern Quebec, Canada). Climate Research, 34(2), 106-117.

Dillon, J. L. (1992). The Farm as a Purposeful System. Miscellaneous Publication No. 10. England, Armidale.

Donatelli, M., Stöckle, C. O., Nelson, R. L., Gardi, C., Bittelli, M., \& Campbell, G. S. (1999). Using the software CropSyst and arcview in evaluating the effect of management in cropping systems in two areas of the low Po valley, Italy. Rev. de Cien. Agric., 22, 87-108.

El-Baroudy, A. A., Ouda, S. A., \& Taha, A. M. (2013). Calibration of CropSyst model for wheat grown in sandy soil under fertigation treatments. Egypt. J. Soil Sci. (In Press).

Gachene, C. K. K., \& Kimaru, G. (2003). Soil fertility and land productivity. Technical Handbook (p. 30). RELMA/Sida Publication, Nairobi Kenya.

Gicheru, P. T., Gachimbi, L. N., Nyangw'ara, M. K., Lekasi, J., \& Sijali, I. V. (2004). Stakeholders consultative meeting on sustainable land management project workshop held at wida highway motel from $1^{\text {st }}-2^{\text {nd }}$ November 2004. Work shop report, Kenya Soil Survey Nairobi.

Grabisch, M. (2003). Temporal scenario modeling and recognition based on possibilistic logic (pp. 261-289). Elsevier Science Publishers Ltd. Essex, UK.

Guzha, A. C. (2004). Effects of tillage on soil micro relief, surface depression storage and soil water storage. Soil and Tillage Research, 76, 105-114. http://dx.doi.org/10.1016/j.still.2003.09.002

Itabari, J. K., \& Wamuongo, J. W. (2003). Water-harvesting technologies in Kenya. KARI Technical Note Series (No. 16).

Jaetzold, R., Schmidt, H., Hornetz, B., \& Shisanya, C. (2006). Ministry of Agricuture Farm Management. Handbook of Kenya (Vol. II, 2nd ed., Part C, Subpart C1). Nairobi, Kenya: Ministry of Agriculture.

Kibunja, C. N., Mwaura, F. B., \& Mugendi, D. N. (2010). Long-term land management effects on soil properties 293 and microbial populations in a maize-bean rotation at Kabete, Kenya. Afr. J. Agric. Res., 5, 108-113.

Klute, A., \& Dirksen, C. (1982). Hydraulic conductivity and diffusivity. In A. Klute (Ed.), Methods of Soil Analysis. American Society of Agronomy. Agron. Monogr. 9. ASA, SSSA, Madison, WI. USA.

Lal, R. (1997). Soil quality and sustainability. In R. Lal, W. H. Blum, C. Valentin \& B. A. Stewart (Eds.), Methods for Assessment of Soil Degradation (pp. 17-31). CRC Press, Boca Raton.

Macharia, P. (2004). Gateway to Land and Water Information: Kenya National Report. FAO (Food and Agriculture Organization). Retrieved from http://www.fao.org/ag/agL/swlwpnr/reports/y_sf/z_ke/ke.htm

Okalebo, J. R, Gathua, K. W., \& Woomer, P. L. (2002). Laboratory methods for soil and plant analysis: A working manual. TSBF: Nairobi, Kenya.

Palm, C. A., Myers, R. J. K., \& Nandwa, S. M. (1997). Combined use of organic and inorganic nutrient sources for soil fertility maintenance and replenishment. In R. J. Buresh et al. (Eds), Replenishing Soil Fertility in Africa (SSA Special Publ. 51, pp. 193-217). SSA, Madison, USA.

Purcell, L. C., Edwards, J. T., \& Brye, K. R. (2007). Soybean yield and biomass responses to cumulative transpiration: Questioning widely held beliefs. Field Crops Research, 101, 10-18. http://dx.doi.org/10.1016/j.fcr.2006.09.002

Roder, W., Mason, S. C., Clegg, M. D., \& Kniep, K. R. (1989). Yield-soil water relationships in sorghum-soybean cropping systems with different fertilizer regimes. Agronomy Journal, 81, 470-475. http://dx.doi.org/10.2134/agronj1989.00021962008100030015x

Sharif, M., Burni, T., Wahid, F., Khan, F., Khan, S., Khan, A., \& Shah, A. (2013). Effect of RP composted with organic materials on yield and phosphorus uptake of wheat and mung bean crops. Pak.. J. Bot.., 45(4), 
1349-1356.

Silva, P. S. L., Silva, J., Oliveira, F. H. T., Sousa, A. K. F., \& Dud, G. P. (2006). Residual effect of cattle manure application on green ear yield and corn grain yield. Horticultura Brasileira, 24, 166-169. http://dx.doi.org/10.1590/S0102-05362006000200008

Sinclair, T. R., \& Seligman, N. G. (1996). Crop modelling: From infancy to maturity. Agron. J., 88, 698-703. http://dx.doi.org/10.2134/agronj1996.00021962008800050004x

Singh, A. K., Tripathy, R., \& Chopra, U. K. (2008). Evaluation of CERES-wheat and CropSyst models for waternitrogen interactions in wheat crop. Agric. Wat. Mang., 95(7), 776-786. http://dx.doi.org/10.1016/j.agwat.2008.02.006

Staggenborg, A. S., \& Vanderlip, L. R. (2005). Crop Simulation Models Can be Used as Dryland Cropping Systems Research Tools. Agronomy Journal, 97, 378-384. http://dx.doi.org/10.2134/agronj2005.0378

Stockel, C. O., Donatelli, M., \& Nelson, R. (2003). CropSyst, a cropping simulation model. European Journal of Agronomy, 18(2008), 289-307.

Stöckle, C. O., Donatelli, M., \& Nelson, R. (2003). CropSyst, a cropping systems simulation model. Eur. J. Agron., 18, 289-307. http://dx.doi.org/10.1016/S1161-0301(02)00109-0

Stöckle, S. M., \& Campbell, G. S. (1994). CropSyst, a cropping systems model: water/nitrogen budgets and crop yield. Agric. Syst., 46, 335-359. http://dx.doi.org/10.1016/0308-521X(94)90006-2

Strudley, W. M., Green, T. R., \& Ascough II, J. C. (2008). Tillage effects on soil hydraulic properties in space and time: State of the science. Soil and Tillage Research, 99, 4-48. http://dx.doi.org/10.1016/j.still.2008.01.007

Taye, B., \& Abera, Y. (2010). Response of Maize (Zea mays L.) to tied ridges and planting methods at Goro, Southeastern Ethiopia. American-Eurasian Journal of Agronomy, 3(1), 21-24.

Tingem, M., Rivington, M., Bellocchi, G., Azam-Ali, S., \& Colls, J. (2008). Comparative assessment of crop cultivar and sowing dates as adaptation choice for crop production in response to climate change in Cameroon. African Journal of Plant Science and Biotechnology, 1, 10-17.

USDA. (1993). Soil Survey Manual. USDA Agricultural Handbook 18. Superintendent of Documents. Washington, DC.

Willmott, C. J. (1982). Some comments on the evaluation of model performance. Bull. Amer. Meteor. Soc., 63, 1309-1313. http://dx.doi.org/10.1175/1520-0477(1982)063\%3C1309:SCOTEO\%3E2.0.CO;2

World Reference Base for Soil Resources (WRB). (2006). A framework for international classification, correlation and communication.

Zougmore, R., Kambou, F. N., Ouattara, K., \& Guillobez, S. (2000). Sorghum-cowpea intercropping: An effective technique against runoff and soil erosion in the Sahel (Saria, Burkina Faso). Arid Soil Research and Rehabilitation, 14, 329-342. http://dx.doi.org/10.1080/08903060050136441

\section{Notes}

Note 1. For Oxen plough only. Similar treatments and cropping sequence was used for TR, and FR.

Note 2. Sweet potatoes were similarly handled as sorghum using same field layout.

\section{Copyrights}

Copyright for this article is retained by the author(s), with first publication rights granted to the journal.

This is an open-access article distributed under the terms and conditions of the Creative Commons Attribution license (http://creativecommons.org/licenses/by/3.0/). 